\title{
Blended Learning Model with IoT-based by Smartphone
}

\author{
https://doi.org/10.3991/ijim.v15i11.22441 \\ Kobchai Siripongdee ${ }^{(凶)}$, Somkiat Tuntiwongwanich, Paitoon Pimdee \\ King Mongkut Institute of Technology, Bangkok, Thailand \\ $57603256 @ \mathrm{kmitl} . \mathrm{ac} . \mathrm{th}$
}

\begin{abstract}
In 2021, the COVID-19 pandemic is still not over. Thailand is the one that is facing the second wave of new coronavirus. Schools and universities were closed, and faculties need to mostly teach with Online pedagogy, including the graduate students' courses. This study proposes to focus on the Ubiquitous area of the Blended Learning model with IoT-based to solve a problem of graduate students and their advisors by the qualitative focus-group technique. The mobile application draft was synthesized and designed to track and monitor graduate students' research activities on smartphones by built-in sensors. They should stay active along while researching the advisor's assignments on their smartphone. Non-active periods are implied when several behaviors are detected. Virtualize dashboards are processed to report the total active learning period of students for the advisor's evaluation.

Moreover, students can continually monitor their self-efficacy to improve the online learning process. Besides, this study proposes to confirm the model's quality by twelve experts with the questionnaire. The results show average scores of Propriety, Utility, Feasibility, and Accuracy standard are 4.32, 4.41, 4.37, and 4.21, respectively. Therefore, the Blended Learning model's overall qualities with IoT-based smartphones are extremely high and proper to implement.
\end{abstract}

Keywords - Blended Learning, IoT-based Technology, Graduate Students, Smartphone, Mobile application

\section{$1 \quad$ Introduction}

Internet network has become a necessity in everyone's digital daily life, especially in the very difficult global situation due to the rapidly and severely spreading of COVID-19 since 2020. Traditional physical behaviors in humans' daily lives were limited and controlled by public health to prevent and stop the virus from spreading. In the blink of an eye, all ordinary lifestyles were changed all over the world. Many physical behaviors were prohibited overnight; all people were forced to change with the new normal behaviors. Internet communication has been pushed to become the necessity for a truly new normal lifestyle such as social distancing, work from home, learn from home, etc. People had been adopted by new regulations for all safety in society. In 2021, the COVID-19 pandemic is still not over. Many countries are still facing the new waves of the new type of coronavirus, COVID-19, and many govern- 
ments still lock down their countries. Besides the big effects on global public health, economics, and society, the education system being impacted in this crisis period. Thailand is the one country that is facing the second wave of new coronavirus. Schools and universities were closed, and faculties need to mostly teach with Online pedagogy, including the graduate students' courses.

The researcher synthesized the Blended learning model with IoT-based technology in the holistic approach into the new normal management model [18]. This new model was categorized into four characteristics, as Figure 1. This model explored the possible and suitable for all educational stakeholders at every level.

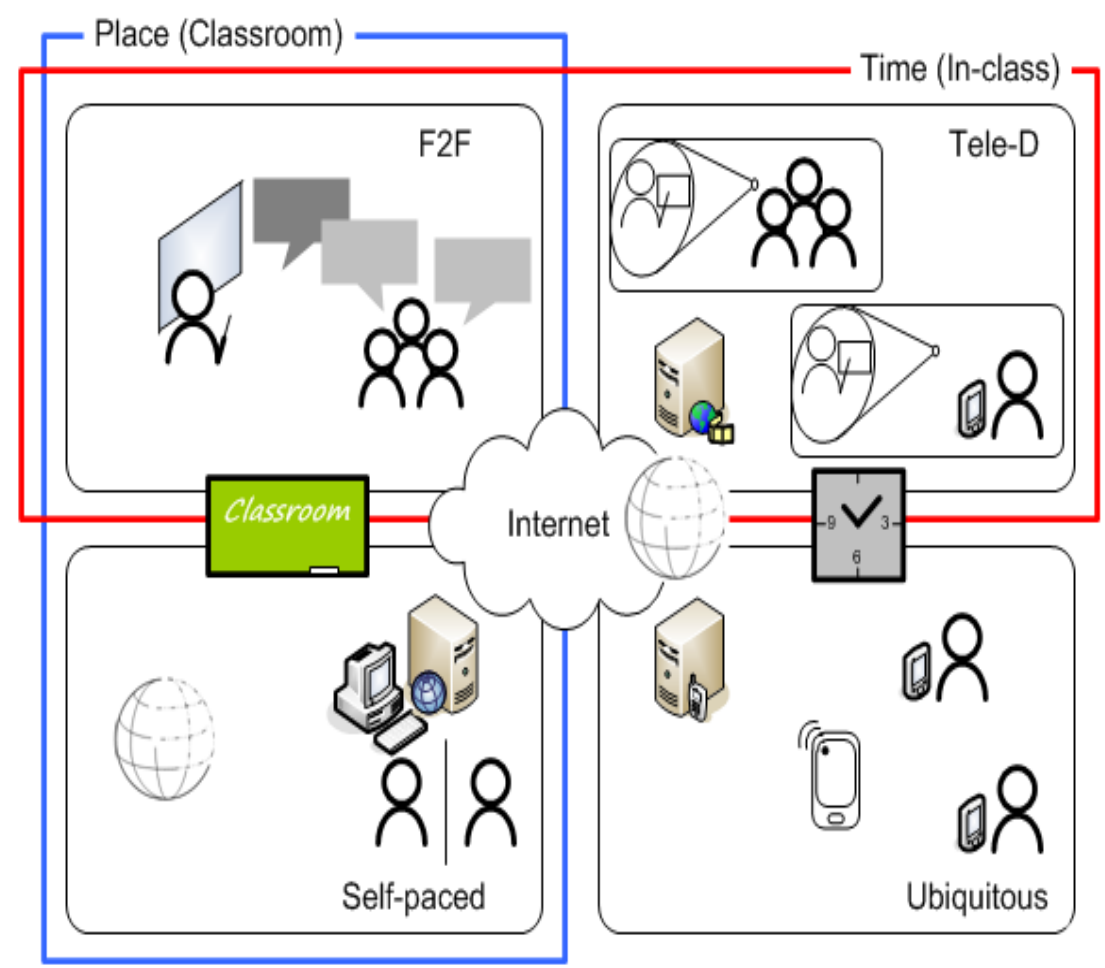

Fig. 1. Four blended learning model characteristics with IoT-based technology [18].

In this study, a graduate student or grad student means a student with a first bachelor's degree pursuing additional education in a specific field, master's, or doctoral degrees for the advanced academic degrees. The researcher was a grad student and had a problem in the dissertation course on the COVID-19 pandemic situation. From the advisors' perspective from the focus-group survey, the classic issue of online teaching in the thesis or dissertation or special-project course of grad students was how to track their students' online learning processes unless the complete task. Many grad students could not stay concentrated or active, along with their online research, because of their responsibilities and roles, including occupational duty, family' loads, 
or social burdens. Some did not research from the primary online sources directly, which made some discrepant information in their knowledge.

Moreover, some students had self-deception which they spent enough time researching, and believed their online learning process was qualified. There were a few factors that are affecting the graduation period of grad students in Thailand. Some characteristics of grad students were found that they usually lack research planning and did not research follow their advisors' advice actively [12][36]. Faculty should provide some mechanisms for advising and follow up the students' performance between grad students and their advisor [12]. Nowadays, the most popular smart device is a smartphone with multipurpose functions and contains different sensor technologies. It was also embedded with many useful built-in sensors, including a camera, barometer, accelerometer, digital compass, GPS, and gyroscope [26][27].

The research question is how to develop the Ubiquitous BL model with IoT-based to solve this problem for grad students in Thailand. Therefore, the researcher tried to efficiently implement this model by designing a mobile application that used the smartphone's built-in sensors to track grad students' behaviors while researching their advisor's assignment on the smartphone.

\section{Related Studies}

\subsection{Blended Learning}

The blended learning (BL) concept was defined and grew up along with internet technology since 1999. BL combined any teaching technologies with face-to-face (F2F) teaching by teacher-led to help learners archive their learning objectives and able to practice both learning and working [21][22][23]. Meanwhile, BL can combine the instructional modalities or delivery media or instructional methods, or computer media into the traditional instruction [9]. Besides, BL can combine the online computer or electronic media with F2F to meet challenges and serve learning goals effectively and efficiently [10][28]. Later, BL course abled to combine online e-learning with traditional classroom to reduce the time of students' attendance by online learning instead [7][13][41]. So, BL was an ongoing long-term integration of information communication technology into education practice normality [3][4]. BL had become an educational approach that enabled the management of learning environments with physical and digital worlds.

\subsection{Internet of Things}

The internet network was born as the United States Department of Defense's ARPA network in 1969 for computer communication. Nowadays, almost all "things" able to connect and communicate through the internet network. Ashton defined the Internet of Things (IoT) in 1999 under the Auto-ID Center project of the Radio Frequency Identification (RFID) technology. Later, the IoT term was combined with the Pervasive computing concept, which was proposed to create smart devices that can com- 
municate through the internet anywhere and anytime. Besides, the progress of wireless communication and high-speed internet technology led IoT into a network of everything, which "things" were the various aspect objects in the whole world and able to be identified and integrated into the communication network. All heterogenous things of IoTs able to generate, exchange, and use digital information with minimum human participation through internet networks. It was the new paradigm to link and communicate of objects which had various size, computation power, energy capacity, and storage capability [11][16][32][39].

Smartphone as an IoT device, there were many distinct types of the sensor embedded in smartphone to enable more implementation of mobile applications more than voice or video communication. Moreover, those sensors can measure the physical motion, sense the location, and sense the surrounding environment. These sensors were classified as inertial, positioning, and ambient sensors [25][27][40]. Meanwhile, some researchers classified it into five categories as optical, thermal, acoustics, magnetic, and mechanical [40]. Therefore, the smartphone was the truly IoT device that more functions need to be explored.

\subsection{Ubiquitous}

Ubiquitous was the big educational concept used as a big comprehensive umbrella to cover all learning visions anywhere and anytime. This idea included u-learning, elearning, and m-learning, in which there were slightly different aspects. Ubiquitous learning was not only identified by reading or listening but occurred through all human senses. Students' ubiquitous activities were directed to seek and solve themselves, foster self-confidence, self-efficacy, and develop their abilities and competence as a part of mental. Learning which is moving towards more IoT devices and environmental context is expected to have some prerequisites and limitations of devices, tools, and contexts such as mobile devices, internet network connection, IoT's wearables, or digital literacy and skills users [15][37]. The ubiquitous concept was recognized as a pedagogy that can help students effectively and efficiently achieve their learning goals. In the educational field, all stakeholders tried to study and develop the Ubiquitous concept. Many educational concepts such as ubiquitous, pervasive computing, e-learning, distance learning, flipped classroom, hybrid classroom, smart classroom, or mobile learning implicated BL and IoT in various degrees, including many terms such as smart space, Technology Enhanced Learning (TEL), Augmented Reality (AR), Learning Management System (LMS), Context-Awareness, Smart Learning Environment (SLE), or intelligence environment. All of these proposed to blend the online digital world into real-life learning while many technologies ready to integrate and foster those concepts such as high-speed 5G cellular, Cloud computing, Big data, and Artificial Intelligence [1][2][5][6][8][14][15][19][24][29][30][31][38].

Nowadays, there was no doubt that smartphones and tablets emerged as a necessary educational alternative for the youth generation. Many mobile applications are self-proclaimed as the proper apps which supported active learning and constructive learning activities. Moreover, mobile apps can promote almost 21 st-century skills such as critical thinking, information literacy, communication, etc. [33]. The educa- 
tional apps for each age level were different in several contexts. For young learners, many educators need more standard evaluation tools for educational apps that parents able to evaluate and consider for their children [34][35]. Many researchers designed many apps for undergraduate students who began to mature and had self-efficacy for self-paced learning. Nevertheless, grad students who had more maturity needed more guidance and follow-up their independent study from their advisor [12][36].

\section{$3 \quad$ Methods}

This study was qualitative research to develop the model and framework of BL model with IoT by smartphone for graduate students in Thailand. First, the qualitative content analysis method was used to synthesize the model based on the previous study [18]. A thematic analysis concentrated on the relationship between content and context that consists of organizing, classifying, comparing, and extracting theoretical conclusions from papers and books [17][20].

Second, the focus-group technique was adopted to conduct, and stakeholders were qualified. Eleven experts attended and discussed the online focus-group meeting through MS-Teams. Simultaneously, the moderator proceeded with session activities, the researcher, as a notetaker, noted all comments to improve the model for the next step.

Third, the questionnaire was conducted as the evaluation tool. The topic and question items were discussed and certified by experts for analysis of the Index of Item Objective Congruence (IOC) by setting the considered criteria to be of good content validity (IOC $>0.50$ ). There were qualified 43 question items and five additional subjective questions in 4 parts of the model's suitability and quality, including Propriety, Utility, Feasibility, and Accuracy standards.

Finally, the qualified experts and specialists in relevant fields include Educational technology, technology, scholarly communication, Electricity and computer engineering, Information and communication technology, and Educational measurement and evaluation amount 12 persons evaluated the model by questionnaire. Then all data were collected and analyzed with quantitative statistics such as Mean and Standard Deviation.

\section{$4 \quad$ Results}

\subsection{Focus-group discussion}

The keys of all comments in the focus group were presented in table 1. 
Table 1. Conclusion of focus-group's comments.

\begin{tabular}{|l|l|}
\hline \multicolumn{1}{|c|}{ Comment's Key } & \multicolumn{1}{|c|}{ Example } \\
\hline $\begin{array}{l}\text { 1. should select some characteristics of the } \\
\text { model to break down in detail for some } \\
\text { specific conditions. }\end{array}$ & $\begin{array}{l}\text { "The potential of IoT to blend is too much, should scope down } \\
\text { for the only type such as Ubiquitous for some course..." } \\
\text { "U-learning can represent other characters..." } \\
\text { "If you can link the context-awareness by sensors, maybe some } \\
\text { interesting dependent variables will be seen..." }\end{array}$ \\
\hline $\begin{array}{l}\text { 2. should define some specific dependent } \\
\text { variables and success indicators. }\end{array}$ & $\begin{array}{l}\text { "Should define this model help teacher or students and how?" } \\
\text { "If you focus on grad students, you need to focus on relative } \\
\text { variables such as self-efficacy. Because grad students have } \\
\text { more maturity and heterogeneous than undergrad..." } \\
\text { "Can IoT try to evaluate students' status or experience?" }\end{array}$ \\
\hline $\begin{array}{l}\text { 3. should select some IoTs as a learning } \\
\text { tool to foster the proper dependent varia- } \\
\text { bles. }\end{array}$ & $\begin{array}{l}\text { "Should survey teachers' problem which model can help to } \\
\text { solve..." } \\
\text { "Should draft some case guideline practice to implement this } \\
\text { model..." } \\
\text { "Subjective IoT devices still expensive to implement..." } \\
\text { "Do you focus on a set learning environment or learning } \\
\text { process?" } \\
\text { "Choose some specific sensors to be an example. It will guide } \\
\text { readers to link to a new proper idea of their own..." }\end{array}$ \\
\hline
\end{tabular}

\subsection{The Blended Learning model with IoT by smartphone for graduate students in Thailand}

From the research's questions, the researcher developed and synthesized the BL model with IoT. Besides, the researcher designed the draft of the mobile application prototype from this model to demonstrate the implementation. The results were presented as follow;

Model framework: From the whole BL model with IoT framework, the researcher selected the Ubiquitous area to design the scope-down framework by smartphone for grad students in Thailand, as Fig 2. Some components in grey color were not considered in this case.

This framework focused on the Ubiquitous area of the model to design the mobile application to track and monitor grad students' research activities on a smartphone. Therefore, a researcher focused only personal context of grad students, which was detected by smartphones as the IoT sensors and IoT devices. All data was collected and processed by the service provider into the student portfolios' database. 


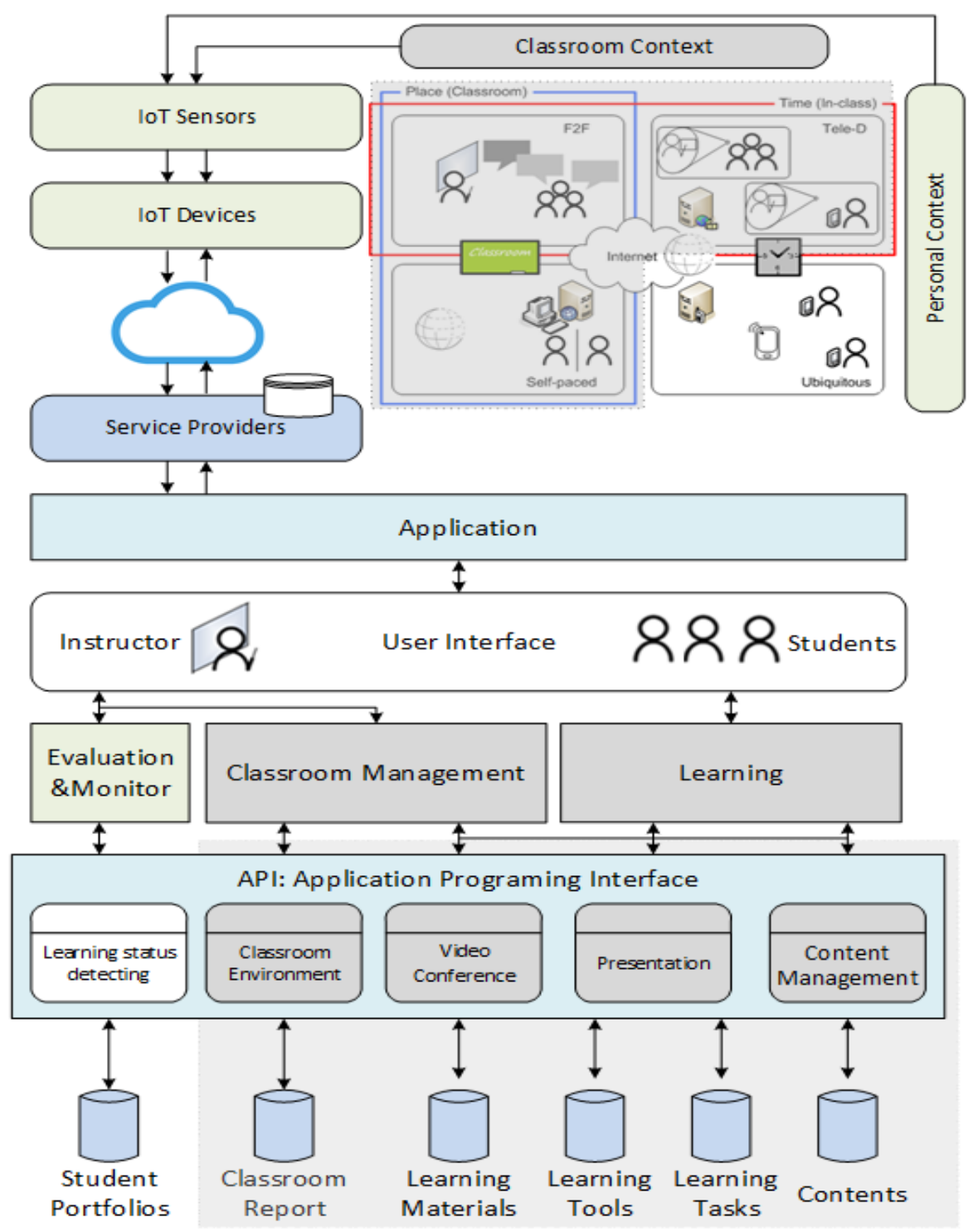

Fig. 2. The scope-down framework of BL model with IoT by smartphone for graduate students in Thailand

The application focused only on the learning status detecting module for monitoring and evaluating students' learning status while using the application on their smartphone by the advisor. In this framework, the learning components were presented in Table 2. 
Table 2. The learning components of this model

\begin{tabular}{|c|c|c|}
\hline Learning component & Ubiquitous model & Description \\
\hline $\begin{array}{l}\text { Tools } \\
\text { Equipment }\end{array}$ & $\begin{array}{l}\text { Smartphone and built-in } \\
\text { context's sensors }\end{array}$ & $\begin{array}{l}\text { Design applications to detect and collect students' } \\
\text { behaviors on a smartphone, such as gesture move- } \\
\text { ment, eye-focus, or screen status, from built-in } \\
\text { sensors. }\end{array}$ \\
\hline $\begin{array}{l}\text { Communication } \\
\text { Technology }\end{array}$ & Cellular network & $\begin{array}{l}\text { Grad students have to be invited by their advisor to } \\
\text { download the app. and sign up by e-mail. }\end{array}$ \\
\hline Interactive & Asynchronous & $\begin{array}{l}\text { 1.Group chatroom for one advisor and his/her group } \\
\text { of grad students. } \\
\text { 2.Individual chatroom with their advisor. }\end{array}$ \\
\hline Environment & Digital world & $\begin{array}{l}\text { Advisor post a primary source link as a task for } \\
\text { his/her students in group-chat or individual-chat. } \\
\text { Students should click to research that primary source } \\
\text { for their learning process. }\end{array}$ \\
\hline Access & By their smartphone & $\begin{array}{l}\text { Students can access their group-chatroom and } \\
\text { individual chatroom to post a message. } \\
\text { The advisor can access both chatrooms to post the } \\
\text { message or task assignment. }\end{array}$ \\
\hline Pedagogy & Online research & $\begin{array}{l}\text { 1. Advisor posts task assignment as a link that } \\
\text { navigates to the primary source to chatrooms. } \\
\text { 2. Students click the task link and research through } \\
\text { an in-app browser. } \\
\text { 3. Application tracks and collects students' behav- } \\
\text { iors through various sensors. } \\
\text { 4. Application processes students' status to report on } \\
\text { the dashboard as visualize. } \\
\text { 5. Advisor monitors students' status and evaluates } \\
\text { students' learning process. } \\
\text { Students evaluate their self-efficacy. }\end{array}$ \\
\hline Evaluation & Active status report & $\begin{array}{l}\text { 1.Group dashboard report for the only advisor. } \\
\text { 2.Individual dashboard for advisor and the owner of } \\
\text { the report. }\end{array}$ \\
\hline
\end{tabular}

System architecture: The system architecture was presented in Fig 3.

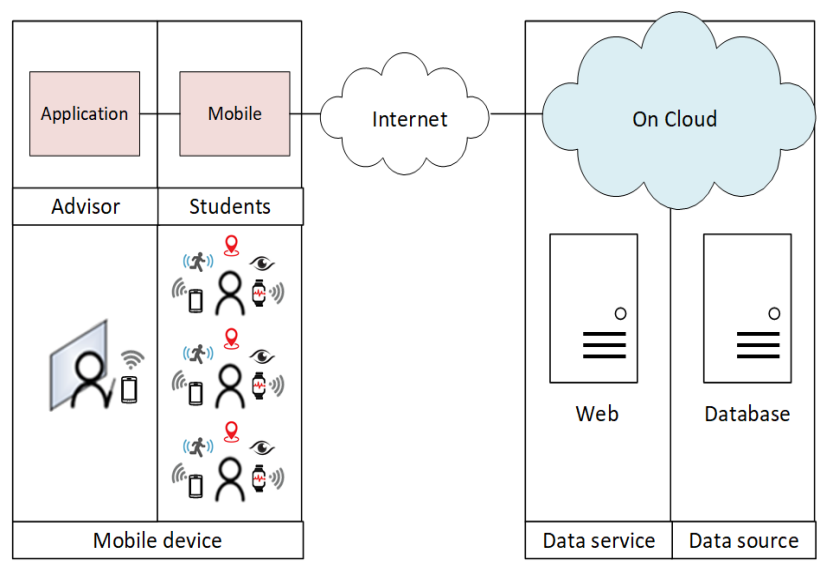

Fig. 3. Smartphone IoT-based BL model system architecture 
Prototype case: This application was designed to collect data of students' behaviors on smartphones while the application was running. The students' status was determined from the criteria logic which recorded "non-active" status when;

- The gyro sensor showed the smartphone was unbalanced.

- The front camera could not detect eye contact.

- GPS. Location changed rapidly, such as move with speed 5-25 km./hr.

- The application was processed in the background.

- The screen did not appear active.

- The microphone detected noise sound around students was over $100 \mathrm{~dB}$.

This information implied that students could not concentrate on researching their smartphones in that period although they ran the application. The researcher drafted the prototype case and defined the mobile application's requirements as the user requirement document in Fig 4.

Next step, the researcher designed a workflow of application as Fig 5. This workflow showed the user journey experience of both advisor and student. The developer or programmer could use this workflow for planning and coding the mobile application later.

In the final step of design, the example wireframe was conducted to guide developers, as Fig 6. After that, the developers' team will be responsible for the rest coding processes to release the final complete mobile application from the BL model with IoT-based smartphone for grad students. 


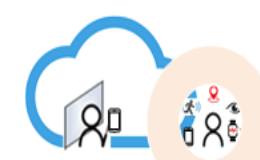

\begin{tabular}{|l|l|}
\hline Target release & 1.0 \\
\hline Epic & Dissertation tracking spp. \\
\hline Document status & Draft \\
\hline Designer & Kobchal S. \\
\hline Developers & Tri J. \\
\hline OA & Paul S. \\
\hline
\end{tabular}

1. Register account as Advisor

2. Administrator approve account

3. Login account

4. Open dashboard (for advisor)

5. Create new chat room

6. Invite students

7. Open chat room

8. Post message/assignment/links

9. View reports
User Journey for Student User

1. Register account as Student

2. Administrator approve account

3. Login account

4. Open dashboard (for student)

5. See invitation pending

6. Open chat room

7. Click on message/assignment

8. Post reply/Click links

9. Research in In-app browser

10. View self-report

\begin{tabular}{|c|c|c|c|c|}
\hline$\#$ & User story title & User story description & Priority & Notes \\
\hline 1 & Roles of users & $\begin{array}{l}\text { Professor Advisor via Graduate Students (Relation } \\
\text { 1:Many) 1) Advisor, 2) Students }\end{array}$ & Must have & $\begin{array}{l}\text { 1. Login by email. } \\
\text { 2. Advisor can invite his/her students in his/her group. (such as } 1-10 \text { persons) }\end{array}$ \\
\hline 2 & Login by email & $\begin{array}{l}\text { Advisor can add his/her students into his/her group } \\
\text { by emall invitation. }\end{array}$ & Must have & $\begin{array}{l}\text { 1) Sign up, 2) Sign in } \\
\text { Student's account need invitation from advisor. }\end{array}$ \\
\hline 3 & $\begin{array}{l}\text { In-Group } \\
\text { communication }\end{array}$ & $\begin{array}{l}\text { Professor able to communicate his/her students } \\
\text { both group.chat and individual-chat. }\end{array}$ & Must have & $\begin{array}{l}\text { 1. In-group chatroom (1 to Many) } \\
\text { 2. Individual chatroom (1 to } 1)\end{array}$ \\
\hline 4 & Browser In-app & $\begin{array}{l}\text { Students open links advisor's link by in-app browser. } \\
\text { Record duration time while student search from the } \\
\text { primary source link }\end{array}$ & Must have & $\begin{array}{l}\text { 1.Detect and collect student's activities in browser include history, time, } \\
\text { gesture movement, eye focus, screen status, etc. into database. } \\
\text { 2.Change Active into Non-active status by criteria from multiple sensors. }\end{array}$ \\
\hline 5 & $\begin{array}{l}\text { Chatroom } \\
\text { theme }\end{array}$ & Simply chatroom like Line's chatroom. & Must have & $\begin{array}{l}\text { Two types of Advisor's chat 1) msg. (No tracking action), 2) task assignment } \\
\text { (with tracking action), One type of student's chat is only msg }\end{array}$ \\
\hline 6 & Status criteria & $\begin{array}{l}\text { App. will process the status' result of student from } \\
\text { activities through smartphone which he/she stay } \\
\text { focus/active to search or not. }\end{array}$ & Must have & $\begin{array}{l}\text { Status "non-active" which; } \\
\text { - gyro sensor show smartphone is unbalance over } 5 \mathrm{sec} \text {. } \\
\text { - front camera cannot detect eye contact over } 10 \mathrm{sec} \text {. } \\
\text { - GPS. location is changed rapidly such as speed } 5-25 \mathrm{~km} \text {. } / \mathrm{hr} \text {. } \\
\text { - App. work in background for } 5 \mathrm{sec} \text {. } \\
\text { - Mobile screen is not active for } 5 \mathrm{sec} \text {. } \\
\text { - Screen standby but no gestures or movements for } 1 \mathrm{~min} \text {. }\end{array}$ \\
\hline 7 & Permission & $\begin{array}{l}\text { Need to request permission to access all sensors of } \\
\text { smartphone such as camera, gps, or gyro sensor. }\end{array}$ & Must have & $\begin{array}{l}\text { Access all relative sensors and privacy information to process student's } \\
\text { context which he/she active or not. }\end{array}$ \\
\hline 8 & Dashboard & $\begin{array}{l}\text { 1) group dashboard (Only for advisor) } \\
\text { 2) Individual dashboard (Only for advisor and owner) }\end{array}$ & Must have & $\begin{array}{l}\text { Show interactive visualize dashboard with Pie-chart, Bar-chart, line graph or } \\
\text { table. }\end{array}$ \\
\hline
\end{tabular}

Fig. 4. The $<$ prototype_app $>$ Requirement \& User Journey. 
Paper-Blended Learning Model with IoT-based by Smartphone

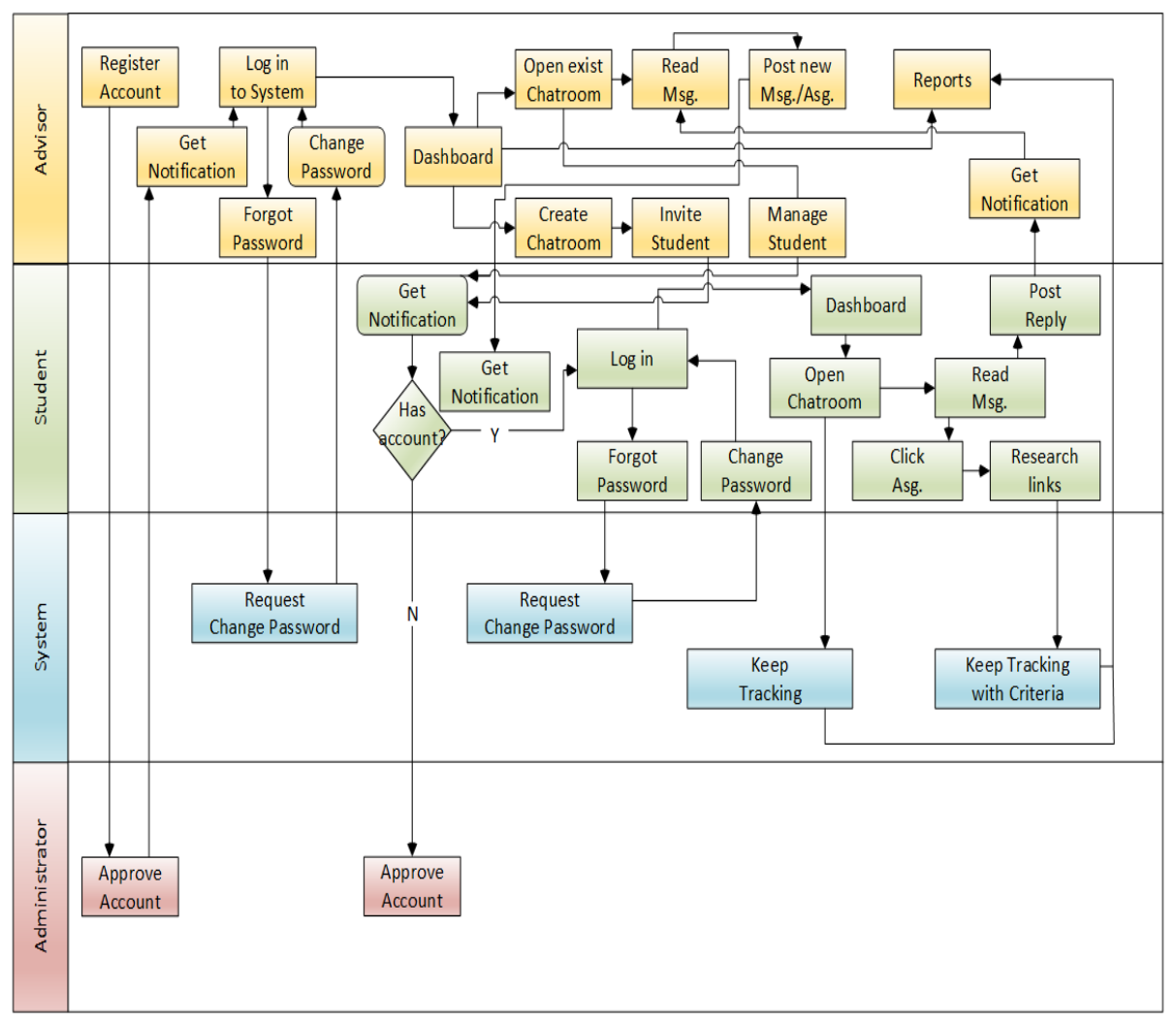

Fig. 5. The $<$ prototype_app $>$ workflow (Swimlane type)

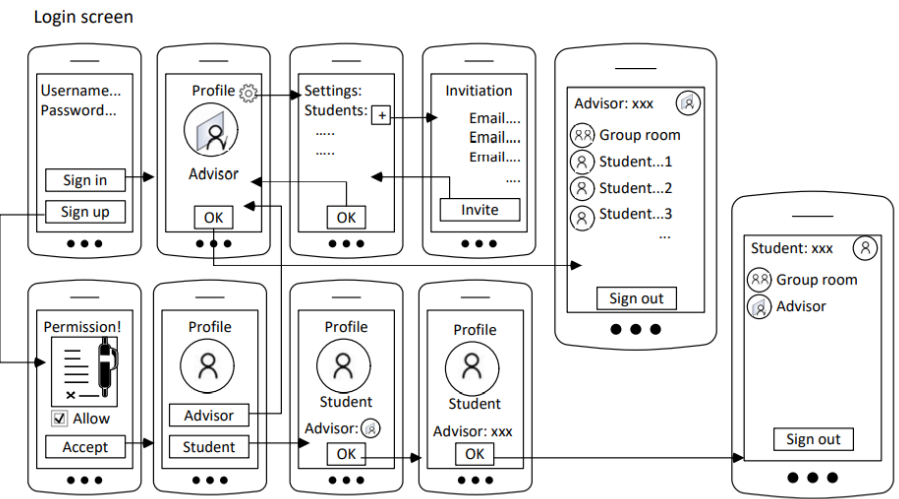



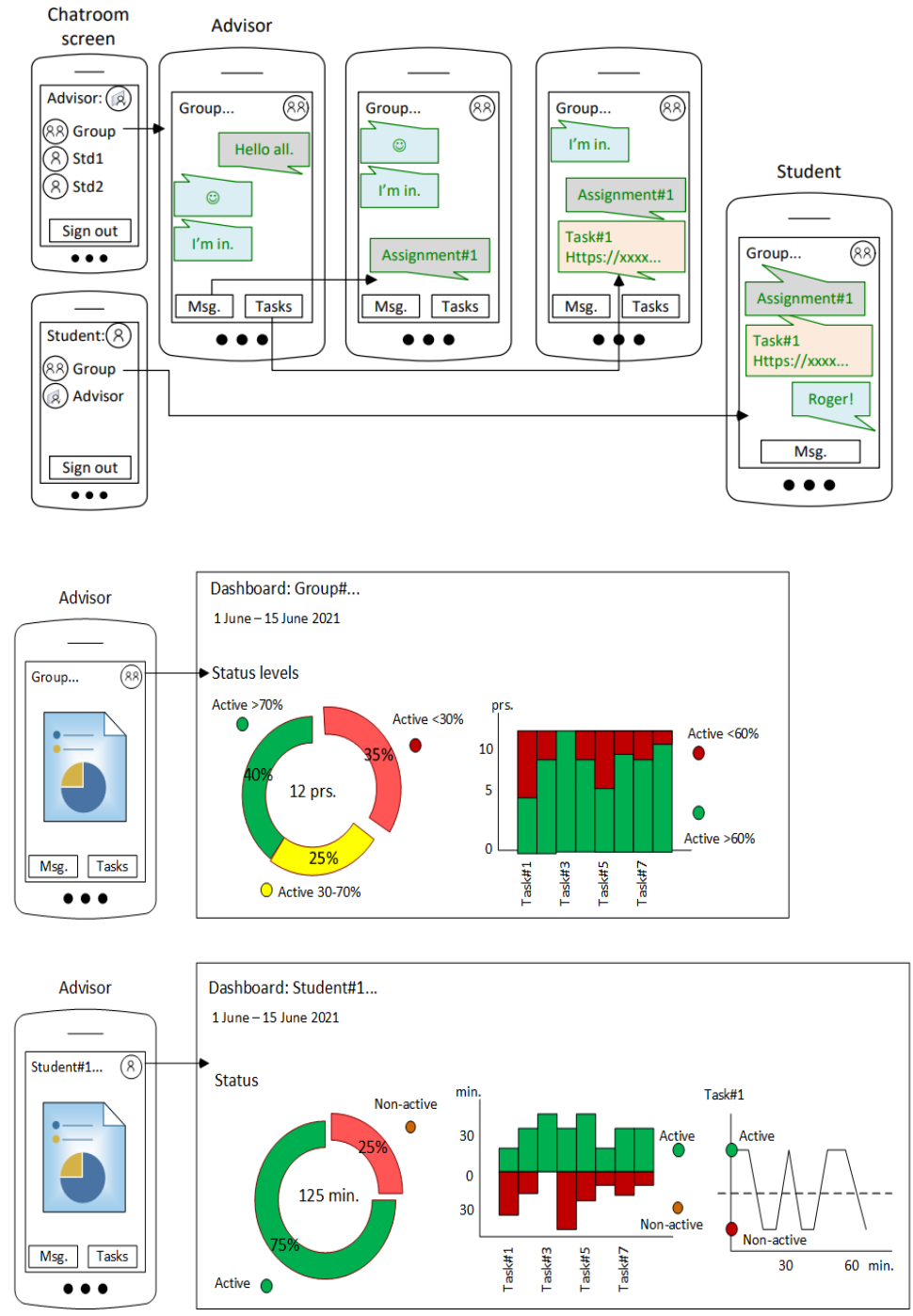

Fig. 6. The $<$ prototype_app $>$ wireframe

\subsection{The quality evaluation of model}

The quality of the BL model with IoT by smartphone for graduate students in Thailand was evaluated by twelve experts specializing in related fields. The questionnaire had four parts of Propriety, Utility, Feasibility, and Accuracy standard. Question items had five levels with variables on a 5-point Likert scale. Rating each level between 1-5 with one being extremely low, Level 2 low, Level 3 moderately, Level 4 high, and Level 5 extremely high. 
All scores were collected and calculated statistically by MEAN and Standard Deviation (SD) (see Table 3 and Table 4). All qualitative addition comments from the questionnaire were collected to improve the model.

The results showed most quality standards of the model were at the highest level. The Propriety, Utility, Feasibility, and Accuracy standard scores were 4.32, 4.41, 4.37, and 4.23.

Table 3. The score conversion to value on a five scales

\begin{tabular}{|c|l|}
\hline Mean score & \multicolumn{1}{|c|}{ Interpretation } \\
\hline $4.21-5.00$ & Extremely high level \\
\hline $3.41-4.20$ & High level \\
\hline $2.61-3.40$ & Moderately level \\
\hline $1.81-2.60$ & Low level \\
\hline $1.00-1.80$ & Extremely low level \\
\hline
\end{tabular}

Table 4. The result of 4 quality standards.

\begin{tabular}{|l|c|c|c|c|c|}
\hline \multirow{1}{*}{ Statistic } & \multicolumn{4}{|c|}{ Standard } & \multirow{2}{*}{ Overall } \\
\cline { 2 - 5 } & Propriety & Utility & Feasibility & Accuracy & \\
\hline MEAN & 4.32 & 4.41 & 4.37 & 4.23 & 4.32 \\
\hline SD & 0.05 & 0.02 & 0.20 & 0.19 & 1.06 \\
\hline Interpretation & $\begin{array}{c}\text { Extremely high } \\
\text { level }\end{array}$ & $\begin{array}{c}\text { Extremely high } \\
\text { level }\end{array}$ & $\begin{array}{c}\text { Extremely high } \\
\text { level }\end{array}$ & $\begin{array}{c}\text { Extremely high } \\
\text { level }\end{array}$ & $\begin{array}{c}\text { Extremely } \\
\text { high level }\end{array}$ \\
\hline
\end{tabular}

\section{Conclusion and Future Work}

This qualitative research focused the BL model with IoT-based smartphones. This study proposed to solve a problem in Thesis, Dissertation, and Special-project course for the teachers and grad students under their supervision. Most advisors needed technology to track their students' learning processes, especially in the online context. This study's results showed a solution from the synthesized model and framework to design a mobile application draft for tracking and evaluating grad students' status while researching smartphones by built-in sensors. Non-active periods are implied when several behaviors are detected, such as the front camera could not detect eye action. The dashboard generated reports as line graphs, bar charts chart, line graphs, and bar charts to show the total and percentage of active learning status. The supervisors or advisors could evaluate their students' learning processes while students could recognize and monitor their self-efficacy and improve their self-paced learning. Finally, the model's quality results by experts shown this model were in the extremely high propriety, utility, feasibility, and accuracy standards.

Although this model ready to implement completely, some issues are still being discussed, such as the right of students' privacy, proper logic of active detection, and mobile coding processes. Meanwhile, some challenges will be faced to create more efficient solutions for the BL model with IoT-based implementation. As this study was focused only on online behaviors on graduate students' smartphones, more context sensors are needed for studying [42][43]. Before anything else, the researcher 
would like to develop this conceptual mobile application with developers and grad students' advisors to tryout and implement for collecting data during this COVID crisis in Thailand as soon as possible. All gathering data will be analyzed and evaluated for initial educational application for grad students.

\section{Acknowledgement}

The researcher greatly appreciated the Faculty of Industrial Education and Technology, King Mongkut Institute of Technology Ladkrabang (KMITL), Thailand, for all academic support in this research.

\section{$7 \quad$ References}

[1] A. Al-Hunaiyyan, S. Al-Sharhan, and R. Alhajri, "A New Mobile Learning Model in the Context of the Smart Classrooms Environment: A Holistic Approach," International Journal of Interactive Mobile Technologies (iJIM), vol. 11, no. 3, p. 39, Apr. 2017, https://doi.org/10.3991/ijim.v11i3.6186

[2] A. Norberg, Å. Händel, and P. Ödling, "Using MOOCs at Learning Centers in Northern Sweden," The International Review of Research in Open and Distributed Learning, vol. 16, no. 6, Dec. 2015, https://doi.org/10.19173/irrodl.v16i6.2035

[3] A. Norberg, B. Stöckel, and M.-L. Antti, "Time Shifting and Agile Time Boxes in Course Design," The International Review of Research in Open and Distributed Learning, vol. 18, no. 6, 2017, doi: https://doi.org/10.19173/irrodl.v18i6.3182

[4] A. Norberg, C. D. Dziuban, and P. D. Moskal, "A time-based blended learning model," On the Horizon, vol. 19, no. 3, pp. 207-216, Aug. 2011, https://doi.org/10.1108 10748121111163913

[5] B. Brumitt, B. Meyers, J. Krumm, A. Kern, and S. Shafer, "EasyLiving: Technologies for Intelligent Environments," Handheld and Ubiquitous Computing, vol. 12, no. 29, p. 12, 2000, https://doi.org/10.1007/3-540-39959-3 2

[6] B. Johanson, A. Fox, and T. Winograd, "The Interactive Workspaces Project: experiences with ubiquitous computing rooms," IEEE Pervasive Computing, vol. 1, no. 2, pp. 67-74, Apr. 2002, https://doi.org/10.1109/mprv.2002.1012339

[7] B. Parsad, L. Lewis, and Westat Peter Tice, "Distance Education at Degree-Granting Postsecondary Institutions: 2006-07," 2008. Accessed: Jan. 2021. [Online]. Available: https://nces.ed.gov/pubs2009/2009044.pdf.

[8] C. Perera, A. Zaslavsky, P. Christen, and D. Georgakopoulos, "Context-Aware Computing for The Internet of Things: A Survey," IEEE Communications Surveys \& Tutorials, vol. 16, no. 1, pp. 414-454, 2014, https://doi.org/10.1109/surv.2013.042313.00197

[9] C. R. Graham, S. Allen, and D. Ure, "Benefits and challenges of blended learning environments," in Encyclopedia of information science and technology, M. Khosrow-Pour, Ed. Hershey, PA: Idea Group., 2005, pp. 253-259. https://doi.org/10.4018/978-1-59140-5535.ch047

[10] C. R. Graham, "Blended Learning system: definition, current trends, and future directions.," in The Handbook of Blended Learning: Global Perspectives, Local Designs, 1st ed., C. J. Bonk and C. R. Graham, Eds. San Francisco, USA: Wiley, John \& Sons, Incorporated., 2006, pp. 1-21. https://doi.org/10.5465/amle.2008.31413871 
[11] D. Miorandi, S. Sicari, F. De Pellegrini, and I. Chlamtac, "Internet of things: Vision, applications and research challenges," Ad Hoc Networks, vol. 10, no. 7, pp. 1497-1516, Sep. 2012, https://doi.org/10.1016/j.adhoc.2012.02.016

[12] D. Khotsumart and C. Apipalakul. "Factors Affecting Graduation Periods of Graduate Students, Khon Kaen University." Journal of Education Graduate Studies Research, 5(3), pp. 17-27, July-Sep. 2012.

[13] E. I. Allen, J. Seaman, R. Poulin, and T. T. Straut, "Tracking online education in the United States,” $2016 . \quad$ [Online]. Available: https://onlinelearningsurvey.com/reports/onlinereportcard.pdf.

[14] G. D. Abowd, "Classroom 2000: An experiment with the instrumentation of a living educational environment," IBM Systems Journal, vol. 38, no. 4, pp. 508-530, 1999, https://doi.org/10.1147/sj.384.0508

[15] I. K. Suartama, P. Setyosari, S. Sulthoni, and S. Ulfa, "Development of Ubiquitous Learning Environment Based on Moodle Learning Management System," International Journal of Interactive Mobile Technologies (iJIM), vol. 14, no. 14, p. 182, Aug. 2020, https://doi.org/10.3991/ijim.v14i14.11775

[16] ITU-T., "Overview of the internet of things, Recommendation ITU-T Y.2060," International Telecommunication Union, 2012. http://handle.itu.int/11.1002/1000/11559

[17] J. W. Creswell, Research Design: Qualitative, Quantitative, and Mixed Methods Approaches, 3rd ed. California, United States of America: SAGE Publications, Inc., 2008.

[18] J. Yang, H. Pan, W. Zhou, and R. Huang, "Evaluation of smart classroom from the perspective of infusing technology into pedagogy," Smart Learning Environments, vol. 5, no. 1, Sep. 2018, https://doi.org/10.1186/s40561-018-0070-1

[19] K. Siripongdee, P. Pimdee, and S. Tungwongwanich, "A blended learning model with IoTbased technology: effectively used when the COVID-19 pandemic?," Journal for the Education of Gifted Young Scientists, vol. 8, no. 2, pp. 905-917, Jun. 2020, https://doi.org/10.17478/jegys.698869.

[20] L. Cohen, L. Manion, and K. Morrison, Research Methods in Education, 6th ed. Abingdon, United Kingdom: Routledge, 2007.

[21] M. Driscoll, "Consultants point of view," 2002. [Online]. Available: https://www07.ibm.com/services/pdf/blended learning.pdf.

[22] M. Driscoll, "Web-Based Training in the Workplace," Adult Learning, vol. 10, no. 4, pp. 21-25, Jun. 1999,

[23] M. Driscoll, Web-Based Training: Creating e-Learning Experiences. Hoboken, NJ: Wiley, 2010.

[24] M. Makolkina, A. Koucheryavy, and A. Paramonov, "The Models of Moving Users and IoT Devices Density Investigation for Augmented Reality Applications," Lecture Notes in Computer Science, vol. 10531, pp. 671-682, 2017, https://doi.org/10.1007/978-3-31967380-6 64

[25] N. D. Lane, E. Miluzzo, H. Lu, D. Peebles, T. Choudhury, and A. T. Campbell, "A survey of mobile phone sensing," IEEE Communications Magazine, vol. 48, pp. 140-150, 2010. https://doi.org/10.1109/MCOM.2010.5560598

[26] N. Katuk, N. H. Zakaria, and K.-R. Ku-Mahamud, "Mobile Phone Sensing using the Builtin Camera," International Journal of Interactive Mobile Technologies (iJIM), vol. 13, no. 02, p. 102, Feb. 2019, https://doi.org/10.3991/ijim.v13i02.10166

[27] of measurement applications on smartphones," Measurement, vol. 46, no. 9, pp. 32913307, Nov. 2013,

[28] R. D. Garrison and N. D. Vaughan, Blended Learning in Higher Education: Framework, Principles, And Guidelines. Hoboken, NJ: Wiley, 2011, pp. 1-8. 
[29] S. A. Hosseini-Tabatabaei, A. Gluhak, and R. Tafazolli, "A survey on smartphone-based systems for opportunistic user context recognition," ACM Computing Surveys (CSUR), vol.45, p. 27, 2013. https://doi.org/10.1145/2480741.2480744

[30] S. Al-Sharhan, "Smart classrooms in the context of technology-enhanced learning (TEL) environment," in Transforming Education in the Gulf Region: Emerging Learning Technologies and Innovative Pedagogy for the 21st Century (Routledge Research in Education), K. Alshahrani and M. Ally, Eds. London: Routledge, 2018, pp. 188-214. https://doi.org/10.4324/9781315621586

[31] S. Freigang, L. Schlenker, and T. Köhler, “A conceptual framework for designing smart learning environments," Smart Learning Environments, vol. 5, no. 1, Oct. 2018, https://doi.org/10.1186/s40561-018-0076-8

[32] S. Li, L. D. Xu, and S. Zhao, "The internet of things: a survey," Information Systems Frontiers, vol. 17, no. 2, pp. 243-259, Apr. 2014,

[33] S. Papadakis, "Apps to Promote Computational Thinking Concepts and Coding Skills in Children of Preschool and Pre-Primary School Age," Mobile Learning Applications in Early Childhood Education, pp.101-121, 2020, https://doi.org/10.4018/978-1-7998-14863.ch006

[34] S. Papadakis, "Tools for evaluating educational apps for young children: a systematic review of the literature," Interactive Technology and Smart Education, vol. ahead-of-print, no. ahead-of-print, Dec. 2020, https://doi.org/10.1108/itse-08-2020-0127

[35] S. Papadakis and M. Kalogiannakis, "A Research Synthesis of the Real Value of SelfProclaimed Mobile Educational Applications for Young Children," Mobile Learning Applications in Early Childhood Education, pp.1-19, 2020, https://doi.org/10.4018/978-17998-1486-3.ch001

[36] S. Supantawee and P. Chairatana, "Problems and Obstacles in Thesis Writing for the Political Science Graduate Students in Master of Arts Special Program, Kasetsart University," Journal of Interdisciplinary Research: Graduate Studies (JIRGS), 7(1), pp. 198-203, 2018. https://doi.org/10.2139/ssrn.3245369

[37] U. YAKAR, A. SÜLÜ, and N. ÇALIŞ, "From Constructivist Educational Technology toMobile Constructivism: How mobile learning serves constructivism?," International Journal of Academic Research in Education, vol. 6, no. 1, Dec. 2020, https://doi.org/10.17985/ijare.818487

[38] W. Xie, Y. Shi, G. X. Xu, and D. Xie, "Smart Classroom - an Intelligent Environment for Tele-education," in Advances in Multimedia Information Processing - PCM 2001, HY. Shum, M. Liao, and SF. Chang, Eds. Berlin: Heidelberg Springer, 2001, pp. 662-668. https://doi.org/10.1007/3-540-45453-5 85

[39] X. Dong, Y. Chang, Y. Wang, and J. Yan, "Understanding usage of Internet of Things (IoT) systems in China," Information Technology \& People, vol. 30, no. 1, pp. 117-138, Mar. 2017, https://doi.org/10.1108/itp-11-2015-0272

[40] X. Su, H. Tong, and P. Ji, "Activity recognition with smartphone sensors," Tsinghua Sci$\begin{array}{lllll}\text { ence and Technology, vol. 19, pp. 235-249, } 2014 . & \end{array}$ https://doi.org/10.1109/TST.2014.6838194

[41] Y. Suo and Y. Shi, "Towards Blended Learning Environment Based on Pervasive Computing Technologies," in Hybrid Learning and Education, 2008, pp. 190-201, https://doi.org/10.1007/978-3-540-85170-7 17

[42] M. Kalogiannakis, S. Papadakis, and Zourmpakis, A.-I, "Gamification in Science Education. A Systematic Review of the Literature," Educ. Sci. 2021, 11, 22. https://doi.org/10.3390

leducsci11010022 
[43] M. Drolia, E. Sifaki, S. Papadakis, and M. Kalogiannakis, "An Overview of Mobile Learning for Refugee Students: Juxtaposing Refugee Needs with Mobile Applications Characteristics," Challenges 2020, 11, 31. https://doi.org/10.3390/challe1102003120

\section{Authors}

Kobchai Siripongdee is a doctoral student of the Educational Technology Program, Faculty of Industrial Education and Technology, King Mongkut Institute of Technology Ladkrabang (KMITL), Bangkok, Thailand. His research focuses on blended learning with IoT-based technology, mobile technologies, and educational innovations and technologies. mailto:57603256@,kmitl.ac.th

Asst. Prof. Somkiat Tuntiwongwanich serves as an assistant professor of curriculum and instruction at Industrial Education and Technology, KMITL, Thailand. His research focuses on teacher education, educational innovations, and professional development. mailto:Somkiat.tu@kmitl.ac.th

Assoc. Prof. Paitoon Pimdee serves as an associate professor with the faculty of Industrial Education and Technology, the Vice President of Procurement at KMITL, Thailand. He is also the Head of his faculty's Ph.D. program. He also holds a Ph.D. in Environmental Education and specializes in environmental behaviors, conservation behaviors, educational research, and statistics. His google scholar citations are located at https://tinyurl.com/y5f19r2a. Paitoon.pi@kmitl.ac.th

Article submitted 2021-03-04. Resubmitted 2021-04-06. Final acceptance 2021-04-06. Final version published as submitted by the authors. 